\title{
Effect of Pre-harvest Application of Gibberellic Acid on Delay in Maturity of Mango cv. Langra
}

\author{
Deen Dayal Singh ${ }^{1}$, R. R. Singh ${ }^{1}$ and Pankaj Kumar Ray ${ }^{2 *}$ \\ ${ }^{1}$ Bihar Agricultural University, Sabour, Bhagalpur, Bihar, India \\ ${ }^{2}$ Horticulture, Krishi Vigyan Kendra, Saharsa, Bihar, India \\ *Corresponding author
}

\section{A B S T R A C T}

\section{Keywords}

Mango tree, Variety

Langra, $\mathrm{GA}_{3}$,

Application date

and Application rate

Article Info

Accepted:

20 December 2020

Available Online:

10 January 2021
Mango (Mangifera indica L.) is one of the most important fruit crops of many tropical and sub-tropical countries of world which belongs to the family Anacardiaceae (Nakasone and Paul 1998 and Purseglove 1972). The experiment was carried out in Horticulture Garden of Bihar Agricultural College, Sabour during Rabi season with the objectives focused in this direction on the effect of GA3 application on physiological regulation of flowering and maturity in mango [Mangifera indica L.] cv. Langra. A critical analysis of data revealed that wide range of phonological observation was observed on morphological traits. The traits such as panicle emergence (14.55 Days), days to $50 \%$ flowering (38.45 Days), bud break to full bloom (45.85 Days) and period of full bloom to maturity (110.43 Days) was recorded with gibberellic acid (GA3) @ 100 ppm, respectively. The other traits like panicles per tree (1044.45) and maximum leaf area $(89.73 \mathrm{~cm} 2)$ were recorded when application of gibberellic acid @ 200 ppm respectively. The other traits like length of panicles $(26.73 \mathrm{~cm})$ were recorded when application of gibberellic acid @ 0 ppm while flowering intensity (67.09 \%) was recorded when spray of gibberellic acid @ 100 ppm. A wide range was observed with application of gibberellic acid on Physiological parameters.

\section{Introduction}

Mango (Mangifera indica L.) is one of the best fruit crops of many tropical and subtropical countries of world which belongs to the family Anacardiaceae (Nakasone and Paul 1998 and Purseglove 1972). Mango is popular and favorite in our country and is relished by people of all the ages because of its attractive appearance, enticing fragrance, rich aromatic flavor and attractive colour. It is found in North-East India, North-Burma and foot hills of the Himalayas and is said to have originated in the Indo-Burma region. India has vast germplasm and varietal diversity with about 1100 named varieties and no other country surpass but in India only few are grown on a commercial scale. Especially in Bihar, there is immense scope of mango crop because the agro-climatic conditions of Bihar are very congenial for mango production and the state has enormous wealth of mango genotypes. 
Mango cv. Langra is predominant variety of Bihar which constitutes about 60 percent area under mango. The availability period of cv. Langra is very short hence it makes glut in the market. The farmers growing cv. Langra are not able to get good remuneration due to short availability. Moreover, the post harvest life of cv. Langra is very poor that make further problem in market.

\section{Materials and Methods}

The field experiment was conducted in AICRP (Fruits) Sabour, in the permanent experimental site under the Department of Horticulture (Fruit \& Fruit Tech.), Bihar Agricultural College, Sabour, Bhagalpur, Bihar. The experimental plot had well drained sandy loam soil of good fertility with leveled surface.

The experiment was carried out on plants those were planted in $1980(33$ year) at AICRP-fruit trial area of Bihar Agriculture College, Sabour. All the trees were maintained under uniform cultural practices during the course of investigation. Trees of mango cv.Langra were sprayed with 50, 100 and $200 \mathrm{ppm}$. Gibberellic acid $\left(\mathrm{GA}_{3}\right)$ at Pea stage. Marble stage, Stone formation stage, 20 and 10 days before harvest. Control trees were spray with water.

\section{Results and Discussion}

The days to panicle emergence of mango cv. Langra was increases significantly with the application of higher concentration of gibberellic acid $\left(\mathrm{GA}_{3}\right)$. The maximum days to panicle emergence (14.55 Days) was recorded with gibberellic acid $\left(\mathrm{GA}_{3}\right)$ sprayed @ 100 ppm while in interaction the maximum days to panicle emergence (17.50 Days) was recorded when gibberellic acid $\left(\mathrm{GA}_{3}\right)$ @ 100 ppm was applied at 10 days before to expected harvest stage. Similar findings were also reported by Elisea \& Devenport (1991) that the spray of $\mathrm{GA}_{3}$ on mango tree which delay bud initiation, thus preventing formation of both vegetative and panicle buds. While, days to $50 \%$ flowering was significantly increases with the application of higher concentration of gibberellic acid $\left(\mathrm{GA}_{3}\right)$.

The maximum days to $50 \%$ of flowering (38.45 Days) were recorded with gibberellic acid $\left(\mathrm{GA}_{3}\right) @ 100$ ppm. The interaction effect of different concentration of gibberellic acid $\left(\mathrm{GA}_{3}\right)$ and time of application was significant effect on the days to $50 \%$ flowering (Table1).Similar results were found by Shinde et al., (2001) recorded that the maximum days to $50 \%$ flowering (81.59 days) with $\mathrm{GA}_{3} @ 100$ ppm in Amrapali.

It was observed that the maximum period of bud break to full bloom (45.85 Days) was recorded with gibberellic acid $\left(\mathrm{GA}_{3}\right) @ 100$ ppm. This was possible due to growing of langra variety of mango in different climate region varying in weather parameters. The interaction effect of different concentration of gibberellic acid $\left(\mathrm{GA}_{3}\right)$ and time of application have significant effect on the period of bud break to full bloom.

The other parameter like period of full bloom to maturity maximum was recorded $(110.43$ Days) with gibberellic acid $\left(\mathrm{GA}_{3}\right) @ 100$ ppm. Similar results was reported by Turnbull et al., (1996) sprayed $\mathrm{GA}_{3}$ or $\mathrm{GA}_{4}$ solutions on mango during winter which caused a delay in flowering time of up to 4 weeks depending on cultivar (Kensington Pride, Glenn, Early Gold) and concentration (50-200 mg/L). Delayed flowering was also resulted to later fruit maturation by up to 2 weeks. Delays in flowering time, which leads to somewhat lesser delayed in fruit maturation, can be achieved with suitable GA treatments (Table$2)$. 
Table.1 Effect of $\mathrm{GA}_{3}$ application on different stages on days to panicle emergence and 50\% flowering in mango cv. Langra

\begin{tabular}{|c|c|c|c|c|c|c|}
\hline \multirow[t]{2}{*}{ Treatments } & \multicolumn{3}{|c|}{$\begin{array}{c}\text { Days to panicle emergence } \\
\text { (Days) }\end{array}$} & \multicolumn{3}{|c|}{$\begin{array}{c}\text { Days to } 50 \% \text { flowering } \\
\text { (Days) }\end{array}$} \\
\hline & 2013-14 & 2014-15 & Pooled & 2013-14 & 2014-15 & Pooled \\
\hline \multicolumn{7}{|l|}{ GA $_{3}$ application } \\
\hline Control & 9.00 & 9.70 & 9.35 & 32.40 & 33.10 & 32.75 \\
\hline 50 ppm & 12.00 & 11.70 & 11.85 & 35.90 & 38.00 & 36.95 \\
\hline 100 ppm & 14.00 & 15.10 & 14.55 & 37.60 & 39.30 & 38.45 \\
\hline 200 ppm & 14.10 & 13.90 & 14.00 & 37.00 & 39.10 & 38.05 \\
\hline $\mathrm{SE} \pm$ mean & 0.39 & 0.32 & 0.25 & 0.455 & 0.387 & 0.299 \\
\hline $\mathrm{CD}(\mathrm{P}=\mathbf{0 . 0 5})$ & 1.16 & 0.94 & 0.72 & 1.346 & 1.146 & 0.855 \\
\hline \multicolumn{7}{|l|}{ Time of application } \\
\hline Pea stage & 9.38 & 11.00 & 10.19 & 32.75 & 36.63 & 34.69 \\
\hline Marble stage & 11.75 & 12.25 & 12.00 & 34.88 & 37.13 & 36.00 \\
\hline Stone formation stage & 12.75 & 12.88 & 12.81 & 35.75 & 36.38 & 36.06 \\
\hline 20 days before expected harvest & 12.50 & 13.25 & 12.88 & 38.25 & 38.50 & 38.38 \\
\hline 10 days before expected harvest & 15.00 & 13.63 & 14.31 & 37.00 & 38.25 & 37.63 \\
\hline $\mathrm{SE} \pm$ mean & 0.44 & 0.35 & 0.28 & 0.508 & 0.433 & 0.334 \\
\hline $\mathrm{CD}(\mathrm{P}=\mathbf{0 . 0 5})$ & 1.30 & 1.05 & 0.81 & 1.505 & 1.281 & 0.956 \\
\hline
\end{tabular}


Table.2 Effect of $\mathrm{GA}_{3}$ application on different stages on period of bud break to full bloom and full bloom to maturity in mango cv. Langra

\begin{tabular}{|c|c|c|c|c|c|c|}
\hline \multirow[t]{2}{*}{ Treatments } & \multicolumn{3}{|c|}{$\begin{array}{l}\text { Period of bud break to full bloom } \\
\text { (Days) }\end{array}$} & \multicolumn{3}{|c|}{$\begin{array}{l}\text { Period of full bloom to maturity } \\
\text { (Days) }\end{array}$} \\
\hline & 2013-14 & 2014-15 & Pooled & 2013-14 & 2014-15 & Pooled \\
\hline \multicolumn{7}{|l|}{$\mathbf{G A}_{3}$ application } \\
\hline Control & 37.10 & 38.10 & 37.60 & 97.65 & 97.48 & 97.57 \\
\hline 50 ppm & 40.40 & 42.80 & 41.60 & 100.07 & 104.93 & 102.50 \\
\hline 100 ppm & 44.60 & 47.10 & 45.85 & 111.31 & 109.55 & 110.43 \\
\hline 200 ppm & 43.70 & 47.00 & 45.35 & 108.92 & 109.16 & 109.04 \\
\hline $\mathrm{SE} \pm$ mean & 0.49 & 0.42 & 0.32 & 0.63 & 0.73 & 0.49 \\
\hline $\mathrm{CD}(\mathrm{P}=\mathbf{0 . 0 5})$ & 1.45 & 1.25 & 0.93 & 1.88 & 2.17 & 1.39 \\
\hline \multicolumn{7}{|l|}{ Time of application } \\
\hline Pea stage & 41.00 & 44.25 & 42.63 & 100.75 & 101.21 & 100.98 \\
\hline Marble stage & 40.13 & 44.88 & 42.50 & 103.46 & 105.05 & 104.26 \\
\hline Stone formation stage & 43.00 & 42.75 & 42.88 & 107.44 & 108.81 & 108.13 \\
\hline $\begin{array}{l}20 \text { days before expected } \\
\text { harvest }\end{array}$ & 43.13 & 42.13 & 42.63 & 107.09 & 107.73 & 107.41 \\
\hline $\begin{array}{l}10 \text { days before expected } \\
\text { harvest }\end{array}$ & 40.00 & 44.75 & 42.38 & 103.70 & 103.60 & 103.65 \\
\hline $\mathrm{SE} \pm$ mean & 0.55 & 0.47 & - & 0.71 & 0.82 & 0.54 \\
\hline $\mathrm{CD}(\mathrm{P}=0.05)$ & 1.62 & 1.40 & NS & 2.10 & 2.43 & 1.55 \\
\hline
\end{tabular}


Table.3 Effect of $\mathrm{GA}_{3}$ application on different stages on number of panicles/tree and length of panicles at anthesis $(\mathrm{cm})$ in mango $\mathrm{cv}$. Langra

\begin{tabular}{|c|c|c|c|c|c|c|}
\hline \multirow[t]{2}{*}{ Treatments } & \multicolumn{3}{|c|}{ No. of panicles/tree } & \multicolumn{3}{|c|}{$\begin{array}{l}\text { Length of panicles at anthesis } \\
\qquad(\mathrm{cm})\end{array}$} \\
\hline & 2013-14 & 2014-15 & Pooled & 2013-14 & 2014-15 & Pooled \\
\hline \multicolumn{7}{|l|}{$\mathbf{G A}_{3}$ application } \\
\hline Control & 962.20 & 610.10 & 786.15 & 26.85 & 26.61 & 26.73 \\
\hline 50 ppm & 1232.00 & 792.30 & 1012.15 & 24.57 & 24.39 & 24.48 \\
\hline 100 ppm & 1129.50 & 705.80 & 917.65 & 24.04 & 23.63 & 23.84 \\
\hline 200 ppm & 1270.00 & 818.90 & 1044.45 & 23.75 & 23.61 & 23.68 \\
\hline $\mathrm{SE} \pm$ mean & 49.15 & 38.07 & 31.09 & 0.59 & 0.65 & 0.44 \\
\hline $\mathrm{CD}(\mathrm{P}=\mathbf{0 . 0 5})$ & 145.48 & 112.70 & 89.00 & 1.74 & 1.91 & 1.25 \\
\hline \multicolumn{7}{|l|}{ Time of application } \\
\hline Pea stage & 1136.75 & 694.38 & 915.56 & 24.94 & 24.46 & 24.70 \\
\hline Marble stage & 1166.25 & 755.25 & 960.75 & 24.21 & 24.36 & 24.29 \\
\hline Stone formation stage & 1190.50 & 745.00 & 967.75 & 24.75 & 24.51 & 24.63 \\
\hline $\begin{array}{l}20 \text { days before expected } \\
\text { harvest }\end{array}$ & 1075.88 & 718.25 & 897.06 & 24.90 & 25.41 & 25.16 \\
\hline $\begin{array}{l}10 \text { days before expected } \\
\text { harvest }\end{array}$ & 1172.75 & 746.00 & 959.38 & 25.21 & 24.05 & 24.63 \\
\hline $\mathrm{SE} \pm$ mean & - & - & - & - & - & - \\
\hline $\mathrm{CD}(\mathrm{P}=\mathbf{0 . 0 5})$ & NS & NS & NS & NS & NS & NS \\
\hline
\end{tabular}


Table.4 Effect of $\mathrm{GA}_{3}$ application on different stages on flowering intensity percent and leaf area $\left(\mathrm{cm}^{2}\right)$ in mango cv. Langra

\begin{tabular}{|c|c|c|c|c|c|c|}
\hline \multirow[t]{2}{*}{ Treatments } & \multicolumn{3}{|c|}{ Flowering intensity $(\%)$} & \multicolumn{3}{|c|}{ Leaf area $\left(\mathrm{cm}^{2}\right)$} \\
\hline & 2013-14 & 2014-15 & Pooled & 2013-14 & 2014-15 & Pooled \\
\hline \multicolumn{7}{|l|}{$\mathbf{G A}_{3}$ application } \\
\hline Control & 49.05 & 71.95 & 60.50 & 97.78 & 79.91 & 88.84 \\
\hline 50 ppm & 52.01 & 77.13 & 64.57 & 81.80 & 93.81 & 87.81 \\
\hline 100 ppm & 53.78 & 80.40 & 67.09 & 84.75 & 83.67 & 84.21 \\
\hline 200 ppm & 50.13 & 74.73 & 62.43 & 89.88 & 89.57 & 89.73 \\
\hline $\mathrm{SE} \pm$ mean & 1.170 & 1.249 & 0.856 & 1.22 & 1.22 & 0.86 \\
\hline $\mathrm{CD}(\mathrm{P}=0.05)$ & 3.462 & 3.697 & 2.450 & 3.61 & 3.60 & 2.47 \\
\hline \multicolumn{7}{|l|}{ Time of application } \\
\hline Pea stage & 49.98 & 77.40 & 63.69 & 85.61 & 102.86 & 94.24 \\
\hline Marble stage & 51.35 & 75.79 & 63.57 & 79.48 & 80.10 & 79.79 \\
\hline Stone formation stage & 52.60 & 75.46 & 64.03 & 102.86 & 85.64 & 94.25 \\
\hline $\begin{array}{l}20 \text { days before expected } \\
\text { harvest }\end{array}$ & 50.83 & 76.77 & 63.80 & 94.41 & 85.61 & 90.01 \\
\hline $\begin{array}{l}10 \text { days before expected } \\
\text { harvest }\end{array}$ & 51.46 & 74.84 & 63.15 & 80.41 & 79.48 & 79.95 \\
\hline $\mathrm{SE} \pm$ mean & - & - & - & 1.36 & 1.36 & 0.96 \\
\hline $\mathrm{CD}(\mathrm{P}=0.05)$ & NS & NS & NS & 4.03 & 4.03 & 2.76 \\
\hline
\end{tabular}


The panicle was found significant in cultivar Langra during its on year (2013) followed by in the on year (2014). It clearly indicated that the number of panicle/tree in all cultivars differ significantly. The number of panicles per tree (1044.45) was found maximum with application of gibberellic acid $\left(\mathrm{GA}_{3}\right)$ @ 200 ppm. However, the minimum number of panicles per tree (786.15) was recorded with gibberellic acid $\left(\mathrm{GA}_{3}\right) \quad @ \quad 0 \quad \mathrm{ppm}$ (Kerdchoechuen and Matta, 2008). The mango panicle is characterized by the growth of the former axes and its size determined by the degree to which these axes elongate. The maximum length of panicles $(26.73 \mathrm{~cm}$.) was found with gibberellic acid $\left(\mathrm{GA}_{3}\right) @ 0 \mathrm{ppm}$ while minimum length of panicles (23.68 $\mathrm{cm}$.) was recorded with the gibberellic acid $\left(\mathrm{GA}_{3}\right) @ 200 \mathrm{ppm}$. There was no significant effect of length of panicles at anthesis with time of application which range from (24.29 $\mathrm{cm}$.) at the marble stage to $(25.16 \mathrm{~cm}$.) at 20 days before to expected harvest. Singh and Rajput (1990) reported that the length of panicle of mango cv. Langra was the greatest $(26.6 \mathrm{~cm})$ when sprayed with $\mathrm{GA}_{3} 30$ ppm @ 50 ppm (Table-3).

The timing and intensity of flowering greatly determines when and how much fruit are produced during a given season. Mango flowering only occurs in tropical warm temperatures in initiating shoots of stems that have achieved sufficient age since the previous vegetative flush, i.e. four to five months depending upon cultivar (Davenport, 2003). The maximum flowering intensity was noticed $(67.09 \%)$ when gibberellic acid $\left(\mathrm{GA}_{3}\right)$ sprayed @ 100 ppm while minimum flowering intensity $(60.50 \%)$ was found @ 0 ppm gibberellic acid $\left(\mathrm{GA}_{3}\right)$. There was no significant effect of flowering intensity with time of application which ranged from $(63.15 \%)$ to $(64.03 \%)$. Shinde et al., 2001 suggested that flowering intensity is determined by the abiotic factors. The maximum leaf area $\left(89.73 \mathrm{~cm}^{2}\right)$ was recorded with gibberellic acid $\left(\mathrm{GA}_{3}\right) @ 200 \mathrm{ppm}$ while minimum leaf area $\left(84.21 \mathrm{~cm}^{2}\right)$ was recorded in gibberellic acid $\left(\mathrm{GA}_{3}\right)$ @ $100 \mathrm{ppm}$ (Notodimedjo, 1997; Notodimedjo, 2000; Sharma and Singh, 2009 and Mostafa and Saleh, 2006) (Table-4).

In conclusion the present study showed that the maximum days to panicle emergence, 50 $\%$ flowering bud break to full bloom and full bloom to maturity was recorded with gibberellic acid $\left(\mathrm{GA}_{3}\right)$ sprayed @ 100 ppm. Period of bud break to full bloom was delayed by eight days with the application of $\mathrm{GA}_{3} @$ $100 \mathrm{ppm}$ as compared to control. The panicle/tree was found significant in cultivar Langra during its on year (2013) followed by in the on year (2014). The number of panicles per tree was found maximum with application of gibberellic acid $\left(\mathrm{GA}_{3}\right) @ 200 \mathrm{ppm}$. There was no significant effect of flowering intensity with time of application which ranged from $(63.15 \%)$ to $(64.03 \%)$. The concentration of $\mathrm{GA}_{3}$ had positive effect on flowering intensity; however the time of application of $\mathrm{GA}_{3}$ did not affect the flowering intensity.

\section{References}

Davenport, T. L., (2003). Management of flowering in three tropical and subtropical fruit tree species. Horti., Science, 38:1331-1335.

Elisea, N. R. \& Davenport, T. L. (1991). Flowering of 'Keitt' mango in response to deblossoming and gibberellic acid. Proc. Flo. State Horti. Soc. 104: 41-43.

Kerdchoechuen Orapin and Matta Frank B. (2008). Flower sex expression in lychee (Litchi chinensis Sonn.) is affected by Gibberellic acid and Naphthalene acetic acid. Int. J. of Fruit Sci., 7(3): 33-40.

Mostafa, E. A. M. and Saleh, M. M. S. (2006). Influence of spraying with 
gibberellic acid on behaviour of Anna apple trees. J. of Applied Sci. Res., 2(8): 477-483.

Nakasone, H. Y. and Paul, R. E. (1998). Tropical Fruits. $C A B$ International, Wallingford, Oxon, UK.

Notodimedjo, S. (1997). Quality of mango (cv. Arumanis) in East Java. Acta Horti., 455: 592-595.

Notodimedjo, S. (2000). Effect of GA3, NAA and CPPU on fruit retention, yield and quality of mango (cv. Arumanis) in East Java. Acta Horti., 509(2): 587-600.

Purseglove, J.W. (1972). Mangoes west of India. Acta Horti., 24: 170-174.

Sharma, R. R. and Singh, R. (2009). GA3 influences incidence of fruit malformation, berry yield and fruit quality in strawberry (Fragaria x ananassa Duch.). Acta Horti., 842: 737740.

Shinde, A. K., Burondkar, M. M., Waghmare, G. M. and Wagh, R. G. (2001). Control of recurring flowering in mango by GA3. Ind. J. of Plant Phy.; 6(1):100102.

Singh, A.K. and Rajput, C.B.S. (1990). Res. Develop. Reporter, 7(1-2): 1-11.

Turnbull, C. G. N., Anderson, K. L. and Winston, E. C. (1996). Influence of gibberellin treatment on flowering and fruiting patterns in mango. Aust. J. Exp. Agr. 36(5): 603-611.

\section{How to cite this article:}

Deen Dayal Singh, R. R. Singh and Pankaj Kumar Ray. 2021. Effect of Pre-harvest Application of Gibberellic Acid on Delay in Maturity of Mango cv. Langra. Int.J.Curr.Microbiol.App.Sci. 10(01): 3502-3509. doi: https://doi.org/10.20546/ijcmas.2021.1001.413 